NBER WORKING PAPER SERIES

\title{
TAXING MULTINATIONALS
}

\author{
Michael P. Devereux \\ R. Glenn Hubbard
}

Working Paper 7920

http://www.nber.org/papers/w7920

\section{NATIONAL BUREAU OF ECONOMIC RESEARCH 1050 Massachusetts Avenue \\ Cambridge, MA 02138 \\ September 2000}

The authors are grateful to the International Tax Policy Forum for financial support. Devereux is also grateful to the Leverhulme Trust for a research fellowship, which also supported the research in this paper. We are grateful to Rosanne Altshuler, Dan Frisch, Bill Gentry, Jane Gravelle, Harry Grubert, James Hines, Peter Merrill, Jack Mintz, Bill Randolph, John Samuels, and seminar participants at Columbia and the American Enterprise Institute for helpful comments and suggestions. The views expressed are those of the authors and not necessarily those of the National Bureau of Economic Research.

(C) 2000 by Michael P. Devereux and R. Glenn Hubbard. All rights reserved. Short sections of text, not to exceed two paragraphs, may be quoted without explicit permission provided that full credit, including (C) notice, is given to the source. 
Taxing Multinationals

Michael P. Devereux and R. Glenn Hubbard

NBER Working Paper No. 7920

September 2000

JEL No. H2

\section{ABSTRACT}

This paper analyzes the effects of tax policy on the strategic choices of a domestic multinational company competing with a foreign multinational company in a third country. We demonstrate the role of the effective average tax rate and the effective marginal tax rate on the company's choices. We consider the impact on national welfare of alternative tax policies for outbound investment. Our results differ from existing models. In contrast to Feldstein and Hartman (1979), in our model, taxing foreign source income on accrual with a deduction for foreign taxes is not generally optimal. However, unlike Mintz and Tulkens (1996), the optimal policy for domestic and outbound investment is linked through the strategic choices of the multinational.

Michael P. Devereux

Department of Economics

Warwick University

Coventry CV4 7AL

United Kingdom

(011) 441203523032

econmd@razor.wbs.warwick.ac.uk

R. Glenn Hubbard

Graduate School of Business

Columbia University

609 Uris Hall, 3022 Broadway

New York, NY 10027

2128543493

and NBER

rgh1@columbia.edu 


\section{INTRODUCTION}

Theoretical and empirical analysis of effects of tax policy on foreign investment has focused on the incentive effects of effective marginal tax rates on investment. While such an emphasis is arguably reasonable for portfolio investment, ${ }^{2}$ it is questionable for foreign direct investment (FDI), which is usually associated with strategic choices, imperfect competition, and the generation of economic rents. In this paper, we build on recent models of multinational firm decision making to develop a framework for evaluating effects of tax policy on the strategic choices of multinationals and on national welfare.

From a national viewpoint, the conventional result for tax policy (since Musgrave, 1963, 1969, and formalized by Feldstein and Hartman, 1979) is that the domestic effective marginal tax rate on outbound FDI should be set equal to the effective marginal tax rate on domestic investment. This would be achieved by taxing the worldwide income of resident multinational firms, but only allowing firms to deduct foreign taxes in determining the home tax base, rather than crediting them. This strategy is intended to achieve production efficiency by equalizing rates of return before home-country taxes, as opposed to before all taxes.

However, this result depends on there being a fixed amount of saving to be divided between domestic investment and outbound FDI. If instead, domestic firms are able to raise finance on the world market, this link between the effective marginal tax

\footnotetext{
${ }^{2}$ For portfolio investment, because the investor can be expected to earn a normal rate of return, modeling the impact of taxation on the required rate of return can reasonably emphasize the effective marginal tax rate. Since the early application of this concept of tax effects by King and Fullerton (1984), researchers have extended the analysis to cross-border investment (see, e.g., Alworth, 1988; OECD, 1991; and Devereux and Pearson, 1995).
} 
rates on the two forms of investment is broken. For example, Mintz and Tulkens (1996)

consider the case in which domestic firms have access to the world capital market, but

where there is some revenue requirement from capital income taxes. In this case they

derive Ramsey-type inverse elasticity rules governing the optimal tax rates on each form

of investment; in general the two optimal tax rates are different from each other. In the

absence of a revenue constraint on capital income taxes (if, for example, public goods can

be funded from other sources of tax), then optimally, both tax rates should be zero. But it

is possible that the domestic tax rate is constrained (as implicitly assumed by Feldstein

and Hartmann, 1979), perhaps because it cannot stray too far from the domestic labor

income tax rate without generating tax avoidance possibilities. In this case, and in the

absence of other linkages between the two forms of investment, the optimal tax rate on

outbound FDI remains zero, even if the tax rate on domestic investment is positive.

In contrast to both of these approaches, the U.S. Treasury has generally advocated the doctrine of capital-export neutrality, under which worldwide efficiency in the allocation of capital is maximized by investors paying equivalent taxes on capital income from marginal investment projects, regardless of the country in which that income is earned (see, e.g., Musgrave, 1963, 1969; and Horst, 1980). ${ }^{3}$ A capital-export-neutral income tax would tax the worldwide income of resident multinational firms and provide a full tax credit for taxes paid abroad, as opposed to a deduction. ${ }^{4}$

\footnotetext{
${ }^{3}$ Using different frameworks for analysis than ours, Frisch (1990) and Hufbauer (1992) have questioned the application of capital-export neutrality to the taxation of multinational firms in the presence of portfolio capital flows and R\&D (and other "headquarters" investment). Grubert and Mutti (1995) argue that these considerations do not overturn the desirability of capital-export neutrality in multinational taxation, though they abstract from the strategic choices we emphasize (and use a different measure of welfare).

4 In practice, tax systems do not correspond to either the conventional national approach, or to capital export neutrality. (For a more detailed description of the U.S. system, see Joint Committee on Taxtation (1993) and Hines and Hubbard (1995). OECD (1991) and Chennells and Griffith (1997) provide detailed international comparisons.) First, no country attempts to tax income when it is earned rather than when it is repatriated. Second, no countries either deduct foreign taxes or give a full credit for foreign taxes in computing the home country tax on foreign source dividend income. Instead, countries either exempt such income, or offer a limited credit system under which the rate of foreign tax credit is limited to the home country domestic corporate tax rate. There have been attempts to explain observed tax systems. For
} 
All of these models are essentially applications of Diamond and Mirrlees (1971), where the optimal tax system generates production efficiency in the presence of perfect competition. By contrast, in this paper, we explore optimal tax policy in the presence of economic rents earned by multinational firms. Economic analysis of the multinational firm in industrial organization generally stresses economic profits from certain activities as a reason both for the firm's existence and for its overseas investment. ${ }^{5}$ Such models are typically based on the "OLI" framework of Dunning $(1977,1981)$, in which advantages to investment through a multinational firm trace to ownership, locational, or internalization advantages (see also the review in Caves, 1996; and Markusen, 1995); more formal models include Horstman and Markusen (1992) and Motta (1992).

In such settings, key decisions about the location of investment (as opposed to marginal expansion of existing investment) are driven by a comparison of after-tax profit among discrete choices. Two factors are important: first, economic rents (from intangibles, cost advantages, or location-specific advantages) constitute at least part of the return on potential projects; and second, decisions involve choices among mutually exclusive locations. There is evidence to suggest that both elements characterize many FDI decisions for multinational firms (see, for example, the review in Caves, 1996). In the presence of these two factors, the relevant concept of "tax" is the fraction of expected profit absorbed by taxation in each choice. Hence the location decision is affected by the effective average tax rate on profit. ${ }^{6}$ An emerging body of empirical work has isolated economically meaningful effects of effective average tax rate measures (or related

example, Bruce (1992) and Gordon (1992) analyze the case of a Stackelberg leader in tax-setting, which by crediting foreign taxes can induce a higher tax rate abroad and so facilitate enforcement of its own sourcebased taxes.

${ }^{5}$ Cummins and Hubbard (1995) review links between the modeling approaches taken by specialists in public economics and industrial organization.

${ }^{6}$ Other examples in industrial organization - including R\&D, constraints on investment imposed by costly external financing of projects, or entrepreneurial selection - also suggest the importance of the effective average tax rate for studying tax policy; see the discussion in Devereux and Griffith (1998a). 
proxies for average rates of taxation) on location and investment decisions by multinational firms. ${ }^{7}$

We build on recent models of multinational firm decision making to develop a simple analytical framework for considering the impact of effective marginal tax rates and effective average tax rates on the strategic choices (e.g., location and production) of multinationals and on national welfare. We do so by applying a general model of the international tax system to an adapted version of the model of Horstman and Markusen (1992), in which two firms resident in different countries (one of which is the home country) compete in a third country, and must decide whether to locate at home or in the third country.

In order to focus on determinants of outbound investment by multinational firms, we first solve the model in a simplified framework, abstracting from taxes outside the home country. After documenting conditions under which effective average tax rates influence strategic choices, we examine the impact of home-country tax policies on the strategic choices of the multinationals. We analyze two regimes: one in which overseas earnings are taxed only on a cash flow basis when repatriated (analogous to "deferral" for active foreign-source income under current U.S. law for investments financed out of retained earnings), and one in which overseas earnings are taxed on an accrual basis. We show that cash flow taxation - implying a zero effective marginal tax rate - generally results in higher pre-tax rents for the nation compared to accrual income taxation.

In the more general model, we consider both the choice between cash flow and accrual taxation and the choice between a deduction and a foreign-tax-credit regime. The results of the more general model are less clear-cut, and depend on the rate of tax levied

\footnotetext{
7 See, for example, Devereux and Griffith (1998b) for an empirical study using a measure of the effective average tax rate, defined in Devereux and Griffith (1998a). Studies using as a measure of the average tax rate defined as current tax liability as a proportion of current income include Collins and Shackelford (1995), Grubert and Mutti (1996), and Altshuler, Grubert, and Newlon (1997).
} 
outside the home country. At low levels of foreign tax, we demonstrate that a tax regime with deferral and a limited foreign tax credit - as is common practice in a number of countries, including the United States and the United Kingdom - generally results in higher national welfare than accrual taxation of foreign-source income with a deduction for foreign taxes, as suggested by Feldstein and Hartman (1979). ${ }^{8}$ However, at high levels of foreign taxation, so much of the economic rent from the investment is captured by the foreign government that the ranking of these two alternative forms of tax is reversed.

A small number of other papers take a similar approach to modeling the impact of taxes on the strategic choices of multinationals, although they differ from the approach in this paper. The closest is Levinsohn and Slemrod (1993), who also analyze the home country's optimal taxation of home and foreign production in the presence of imperfect competition among multinational duopolists. However, there are several important differences. First, in our model firms make a discrete choice between producing at home or abroad, which generates an important role for the effective average tax rate. By contrast, Levinsohn and Slemrod assume that each firm produces in both locations, and chooses only the split of production between the two. Second, we model explicitly the taxation of domestic and foreign source capital income, paying particular attention, for example, to whether any foreign tax is creditable or deductible. By contrast again, Levinsohn and Slemrod model output taxes and tariffs; partly as a result, their conclusion that "the optimal tax rate on foreign source income does not depend on the rate imposed in the host country" is starkly different from our results.

Other papers focus on optimal taxation in the host country. For example, Janeba (1996) analyzes a model in which a multinational firm and a domestic firm both produce in the same country; the strategic interaction between them is only through output, rather

8 The basic insight of the Feldstein-Hartman result can also be found in Musgrave $(1963,1969)$. 
than through choice of the location or production. Janeba (1998) extends the BranderSpencer (1986) strategic trade policy model to allow for mobile firms and finds that mobility of firms overturns the incentive to subsidize exports. However, this depends on a uniform tax being levied in the host country; implying that foreign firms locating in a country would also receive any subsidy paid. Haufler and Wooton (1997) analyze a model in which two countries compete to attract a single monopolist.

This paper is organized as follows. In section II, we develop a model of a home firm and a foreign firm each choosing among three strategies: (A) do not serve the foreign market; (B) export to the foreign market; and (C) produce abroad to serve foreign market (entailing FDI). We model the domestic tax system, but assume that there is no foreign tax. Section III presents the more general model. Section IV concludes and considers the results of the model in evaluating conventional norms for international tax policy.

\section{A SIMPLIFIED MODEL OF FOREIGN DIRECT INVESTMENT IN THE PRESENCE OF CAPITAL INCOME TAXES}

In what follows, we adapt the model of Horstmann and Markusen (1992), who study the role of fixed costs and transport costs in the strategic choices of multinationals, in order to analyze trade flows, foreign direct investment, and market structure. We consider the choice of a home-country multinational of whether to supply a market in a foreign country, and if so, whether to do so by producing at home or abroad. Choosing to

produce abroad involves a fixed cost of $F$. In the more general model of section III, we allow for a tax levied by the home country on corporate income generated both at home 
and abroad, and a tax levied by the foreign country on outward investment. However, in this section we present a simplified and more tractable version of the general model, in which the foreign country does not levy a tax. We set up the model in several stages below.

\section{A. Defining Strategic Choices}

We examine the case of a single firm resident in the home country, $H$, considering whether and how to sell good $X$ in a foreign country, $G .{ }^{9}$ The firm faces potential competition in $G$ from an (identical) single "foreign" firm resident in a third country, $E$, which in principle sells a differentiated good, $Y$. However, to fix ideas, we begin by restricting the two goods to be identical; this simplification has no impact on the qualitative results. In this case, $X$ denotes the output of the home firm, and $Y$ denotes the output of the foreign firm. There are two periods, and production and sales to the foreign market both take place in the second period. Where investment occurs, it takes place in the first period. At the end of the second period, the firm closes down and pays all remaining cash to shareholders as dividends. The firm's discount rate is $r$; this is simply the rate of return in the international capital market. One can assume, for example, that shareholders are resident in $H$, but have free access to world markets.

Each firm considers the three strategies:

(A): do not serve the foreign market;

(B): export to the foreign market; and

(C): produce abroad to serve the foreign market.

The demand for the final good in $G$ is given by an inverse demand curve:

\footnotetext{
9 For an excellent survey of models of "strategic trade policy" in industrial organization and international trade, see Brander (1995). Models of an international Cournot duopoly competing in a third market (akin to the structure we use here) trace their roots to Brander and Spencer (1985).
} 


$$
p_{i j}=a-b\left(X_{i j}+Y_{i j}\right)
$$

where $p$ is the price of the final good. Prices and quantities are indexed by $(i, j)$, where $i=$ $\mathrm{A}, \mathrm{B}, \mathrm{C}$ represents the choice of the home firm and $j=\mathrm{A}, \mathrm{B}, \mathrm{C}$ represents the choice of the foreign firm.

Strategic choice B incurs transport costs to $G$ of $s$ per unit of exports. In general, strategic choices $\mathrm{B}$ and $\mathrm{C}$ require new investment in the first period of $K_{i j}^{\prime}$. It is useful to express this is as a second-period value of $K_{i j}=(1+r) K_{i j}^{\prime}$. We further make the simplifying assumption of a fixed capital-output ratio, so that, for example, $K_{i j}=m X_{i j}$. There is also a fixed cost associated with strategic choice $\mathrm{C}$ in the first period of $F^{\prime}$. Again, it is useful to express this in second-period terms as $F=(1+r) F^{\prime}$. Investment in strategic choice $\mathrm{C}$ is undertaken by a wholly-owned affiliate in $G$. The investment can be financed either through new equity from the parent firm, or a reduction in dividends paid by an existing affiliate to its parent in the first period.

In the absence of tax, the profit levels of the alternative strategies for the home firm, $V_{i j}^{*}$, and the foreign firm, $Z_{i j}^{*}$, expressed in second-period values, are therefore:

Strategy A:

$$
V_{A j}^{*}=0 \quad Z_{i A}^{*}=0
$$

Strategy B:

$$
\begin{aligned}
V_{B j}^{*} & =\left(p_{B j}-s\right) X_{B j}-K_{B j} & Z_{i B}^{*} & =\left(p_{i B}-s\right) Y_{i B}-K_{i B} \\
& =\left(p_{B j}-s-m\right) X_{B j} & & =\left(p_{i B}-s-m\right) Y_{i B}
\end{aligned}
$$

Strategy $C$ :

$$
\begin{aligned}
V_{C j}^{*} & =p_{C j} X_{C j}-\left(K_{C j}+F\right) & Z_{i C}^{*} & =p_{i C} Y_{i C}-\left(K_{i C}+F\right) \\
& =\left(p_{C j}-m\right) X_{C j}-F & & =\left(p_{i C}-m\right) Y_{i C}-F
\end{aligned}
$$


Assuming Cournot competition between the two firms in the foreign market and substituting the demand function (1) into the expressions for profit, it is straightforward to derive for each pair of strategic choices the optimal level of output for each firm.

Substituting back into the expressions for profit yields the post-tax level of profit for each combination of strategies, and hence the market structure defined by the Nash equilibria. We follow this approach below. However, before doing so, it is necessary to define the tax systems to be analyzed.

\section{B. Introducing Taxation}

We consider a standard corporation tax levied in the home country (at a statutory tax rate of $t$ ). The present value of depreciation allowances per unit of capital expenditure, $K_{i j}$, is denoted by $A$. We assume that transport costs are fully deductible. Hence the post-tax level of profit from strategy B is:

$$
\begin{aligned}
V_{B j} & =(1-t)\left(p_{B j}-s\right) X_{B j}-(1-A) K_{B j} \\
& =(1-t)\left(p_{B j}-s-\gamma m\right) X_{B j},
\end{aligned}
$$

(3a)

where $\gamma=\frac{(1-A)}{(1-t)}$ is a factor which reflects the generosity of the provision for depreciation. In general, $\gamma \geq 1 ;{ }^{10} \gamma=1$ is the case of cash flow taxation.

The taxation of outbound investment is more complex, depending on whether the home country taxes profits earned abroad on accrual or on repatriation to the home country. In the former case -- and in the absence of tax in the foreign country -- the tax system is identical to that for domestic investment in the home country. However, in the latter case, the home country taxes the repatriation of dividends rather than foreign 
profits. Again in the absence of foreign taxes, the home country tax rate applied to these dividends is simply $t$. In the second period, the foreign affiliate closes down and pays all its remaining value to the parent firm in the form of dividends. This payment is therefore taxed at rate $t$. $^{11}$

However, the value of allowances depends on how the investment is financed. Suppose first that it is financed by retaining earnings in the subsidiary in the first period. Then repatriated dividends in the first period fall by the cost of the investment, and the tax falls by a proportion $t$ of this amount. Such tax treatment is akin to cash flow taxation with new investment receiving a full allowance. By contrast, if the investment is financed by new equity, then no tax relief can be claimed in the first period. However, we assume that the initial equity capital investment can be repaid to the parent in the second period without incurring the tax on dividends; the net present value of this tax relief is $t /(1+r)$.

Denoting the net present value of the relief for investment to be $\alpha$ :

\begin{tabular}{|c|c|c|}
\hline$\alpha$ & Retained earnings & New equity \\
\hline Deferral & $t$ & $t /(1+r)$ \\
\hline Non-deferral & $A$ & $A$ \\
\hline
\end{tabular}

Defining $\eta=\frac{(1-\alpha)}{(1-t)}$, we can express the post-tax value of the strategy $C$ to be written as:

\footnotetext{
${ }^{10}$ Although it can take values less than 1.

${ }^{11}$ An alternative characterization of the "rent" we describe is a "royalty" to compensate the parent firm for some home-country investment in, say, advertising or R\&D. In that characterization, the rent should be repatriated as a royalty, and we should then confine our attention to the normal return.

We do not believe this characterization is useful for two reasons. First, it is by no means clear in practice that overseas rents are created only by domestic investments (i.e., Pepsi may have to advertise in Korea to create brand loyalty there). In the context of our analytical example, suppose the parent firm is deciding between cases of producing at home for export (with rent $R_{1}$ ) and producing abroad (with rent $R_{2}$ ). If $R_{2}>$ $R_{l}$, it is due to exploiting conditions in the host country. Second, even if the rent were "domestic," our inquiry regards the optimal taxation of foreign-source income (in our model), not current tax practice.
} 


$$
\begin{aligned}
V_{C j} & =(1-t) p_{C j} X_{C j}-(1-\alpha) K_{C j}-(1-\hat{\alpha}) F \\
& =(1-t)\left(p_{C j}-\eta m\right) X_{C j}-(1-t) \hat{\eta} F .
\end{aligned}
$$

This formulation allows the fixed cost $F$ to take the form of (i) depreciable capital investment, in which case $\hat{\alpha}=\alpha$ and $\hat{\eta}=\eta$; or (ii) a deductible expense, in which case $\hat{\alpha}=t$ and $\hat{\eta}=1$ unless the tax system is deferral and the investment is financed by new equity, in which case, $\hat{\alpha}=\alpha$ and $\hat{\eta}=\eta$.

\section{Measuring Welfare}

We are concerned with the choice of tax system by the government of the home country, $H$. In order to analyze this choice we use a simple measure of the welfare of the home country: the pre-tax value of the investment, $V_{i j}^{*} \cdot{ }^{12}$ In essence, this is a measure of the impact on the wealth of the country undertaking the investment project, without any consideration of the distribution between the government and the private sector. ${ }^{13}$

Following Feldstein and Hartman (1979), we generally assume that the domestic tax system, here summarized by $t$ and $A$, is given and we consider the optimal taxation of outbound investment conditional on this domestic tax system. In doing so, we do not impose any revenue requirements. Of course, there are alternative approaches: for example, to choose all the elements of the tax system jointly subject to a revenue requirement. However, the focus of this paper is not on the optimal structure of the corporation tax itself, but on the taxation of outbound investment given a domestic tax system. In practice, it is hard to believe that there is a serious revenue constraint applying to tax raised from outbound investment per se because such tax revenues are usually very small relative to total tax revenues.

\footnotetext{
${ }^{12}$ In the general case in which the foreign country levies tax, this is instead defined net of foreign taxes.

${ }^{13}$ That is, we assume that the marginal cost of public funds is unity.
} 


\section{Determining Output and Profit for Each Combination of Strategies}

We assume that the two firms play Cournot; that is, each firm chooses its optimal output level conditional on the strategy and the level of output of the other firm. It does so by maximizing the profit of the strategy -- $V_{i j}$ and $Z_{i j}^{*}$, respectively, for the home and foreign firm --subject to the demand equation (1). Thus, for any output level chosen by the foreign firm, $Y_{i j}$, the home firm sets $X_{i j}$ as:

$$
\begin{gathered}
X_{A j}=0, \\
X_{B j}=\frac{a-s-\gamma m-b Y_{B j}}{2 b},
\end{gathered}
$$

and

$$
X_{C j}=\frac{a-\eta m-b Y_{C j}}{2 b}
$$

Similarly, the foreign firm sets:

$$
\begin{gathered}
Y_{i A}=0, \\
Y_{i B}=\frac{a-s-m-b X_{i B}}{2 b},
\end{gathered}
$$

and

$$
Y_{i C}=\frac{a-m-b X_{i C}}{2 b} .
$$

For further simplicity, we assume values of the parameters which rule out either firm choosing strategy A. Combining these output levels conditional on the strategic choice generates the output levels summarized in Table 1, for each strategic choice.

The output terms reflect the severity of each tax system. Thus, for example, if the home country $H$ offers low allowances on domestic investment, then $A$ is low and $\gamma$ is 
relatively high. This configuration of parameters implies a higher marginal effective tax rate faced by the home firm on domestic investment, and hence a lower optimal level of output, given strategic choice B. By contrast, however, because the home firm chooses a lower level of output in this case, the foreign firm chooses a higher level of output - that is, a higher $\gamma$ implies a higher output of the foreign firm, conditional on the home firm's choosing strategy B. The corresponding tax parameter when the home firm chooses strategy $\mathrm{C}$ is $\eta$, which works in exactly the same way.

TABLE 1

Output Levels Conditional on Strategic Choice

\begin{tabular}{|c|c|c|}
\hline \multirow{2}{*}{$\begin{array}{c}\text { Home firm } \\
\text { chooses }\end{array}$} & \multicolumn{2}{|c|}{ Foreign firm chooses } \\
\cline { 2 - 3 } & $\mathrm{B}$ & $\mathrm{C}$ \\
\hline \multirow{2}{*}{$\mathrm{B}$} & $X_{B B}=\frac{a-s+m(1-2 \gamma)}{3 b}$ & $X_{B C}=\frac{a-2 s+m(1-2 \gamma)}{3 b}$ \\
& $Y_{B B}=\frac{a-s-m(2-\gamma)}{3 b}$ & $Y_{B C}=\frac{a+s-m(2-\gamma)}{3 b}$ \\
\hline $\mathrm{C}$ & $X_{C B}=\frac{a+s+m(1-2 \eta)}{3 b}$ & $X_{C C}=\frac{a+m(1-2 \eta)}{3 b}$ \\
& $Y_{C B}=\frac{a-2 s-m(2-\eta)}{3 b}$ & $Y_{C C}=\frac{a+m(2-\eta)}{3 b}$ \\
\hline
\end{tabular}

Substituting the output values reported in Table 1 into the demand equation (1) and the expressions for the value of each strategy for each firm in (2) yields the pairs of values of $V$ and $Z^{*}$ corresponding to each pair of strategies chosen by the two firms. These are summarized in Table 2. 
TABLE 2

Profit Levels Conditional on Strategic Choice

\begin{tabular}{|c|c|c|}
\hline \multirow{2}{*}{$\begin{array}{l}\text { Home } \\
\text { firm } \\
\text { chooses }\end{array}$} & \multicolumn{2}{|c|}{ Foreign firm chooses } \\
\cline { 2 - 3 } & $\mathrm{B}$ & $\mathrm{C}$ \\
\hline \multirow{2}{*}{$\mathrm{B}$} & $V_{B B}=(1-t) b X_{B B}^{2}$ & $V_{B C}=(1-t) b X_{B C}^{2}$ \\
& $Z_{B B}^{*}=b Y_{B B}^{2}$ & $Z_{B C}^{*}=b Y_{B C}^{2}-F$ \\
\hline $\mathrm{C}$ & $V_{C B}=(1-t)\left\{b X_{C B}^{2}-\hat{\eta} F\right\}$ & $V_{C C}=(1-t)\left\{b X_{C C}^{2}-\hat{\eta} F\right\}$ \\
& $Z_{C B}^{*}=b Y_{C B}^{2}$ & $Z_{C C}^{*}=b Y_{C C}^{2}-F$ \\
\hline
\end{tabular}

\section{E. Some Implications of the Model}

Before investigating the Nash equilibria, we consider four implications for firm decisions of introducing a home country tax.

1. The strategic choice depends on the effective average tax rate, rather than on the effective marginal tax rate. In the absence of tax the optimal strategy (conditional on a strategy of the foreign firm) is to choose the strategy, $i=\mathrm{A}, \mathrm{B}$, or $\mathrm{C}$, which generates the highest pre-tax net present value, $V_{i j}^{*}$. In the presence of tax, the optimal strategy is that which generates the highest post-tax net present value, $V_{i j}$. A natural definition of the effective average tax rate $(E A T R)$ in this setting is the proportion of the pre-tax value captured in tax:

$$
E A T R_{i j}=T_{i j}=\frac{V_{i j}^{*}-V_{i j}}{V_{i j}^{*}} .
$$

Using this definition, the strategic choice in the presence of tax can be expressed as:

choose the strategy with the highest $V_{i j}^{*}\left(1-T_{i j}\right)$. For the strategic choice $\mathrm{B}$, the EATR is 


$$
\mathrm{E}_{A T R_{B j}}=T_{B j}=1-\frac{(1-t) X_{C j}^{2}}{X_{C j}^{* 2}} .
$$

It is straightforward to show that $\gamma \geq 1 \Rightarrow X_{B j}^{*} \geq X_{B j} \Rightarrow T_{B j} \geq t$. That is, a cash flow tax $(A=t \Rightarrow \gamma=1)$ yields an $E A T R$ equal to the statutory rate. A less generous depreciation provision results in the EATR being higher than the statutory rate. For the strategic choice $\mathrm{C}$,

$$
E_{A T R_{C j}}=T_{C j}=1-\frac{(1-t)\left(b X_{C C}^{2}-\hat{\eta} F\right)}{\left(b X_{C C}^{* 2}-F\right)} .
$$

As in the previous case, $\eta \geq 1 \Rightarrow X_{C j}^{*} \geq X_{C j} \Rightarrow T_{C j} \geq t$, whether or not the fixed cost is immediately deducted or depreciated as an investment.

In general, this measure of the EATR has the property that for a very profitable investment, as $V_{i j}^{*} \rightarrow \infty$ then $E A T R_{i j} \rightarrow t$. At the other extreme, as $V_{i j}^{*} \rightarrow 0$ then $E A T R_{i j}$ $\rightarrow \infty .{ }^{14}$ As the next two implications make clear, there are two special cases worth noting.

2. A tax system with deferral, and investment financed by retained earnings, (i.e., $\alpha=t)$ has $T_{\mathrm{C} j}=t$. This follows immediately from the previous analysis. The implication is that in this case, the tax system for outbound investment is in effect a cash flow tax, and thus generates an EATR equal to the statutory rate (and an effective marginal tax rate of zero).

3. Conditional on the strategic choice, tax does not affect investment decisions if $\gamma=1$ and $\eta=1$. If $\gamma=1$ and $\eta=1$, output levels - conditional on the strategic choice are the same as in the absence of tax. This reflects the well-known result that a cash-flow tax (or equivalent) results in all cash flows -- and hence the net present value of the 
investment -- being reduced in the same proportion (i.e., $t$ ). This implies that the effective marginal tax rate is zero; an investment with a zero net present value is not taxed in present value terms. In addition, $\gamma=1$ and $\eta=1$ implies that the $E A T R=t$ for strategies $\mathrm{B}$ and $\mathrm{C}$, which in turn implies the tax does not affect the strategic choice.

4. A tax on accrual (i.e., in the absence of deferral) imposed by the home country will not affect the strategic choice if: (i) the income stream is independent of tax (ii) there is a residence-based comprehensive income tax and (iii) the tax depreciation allowance is equal to the net present value of the income stream. This is simply an application of Samuelson's (1964) invariance proposition, and so will not be proved here. An implication is that, if all countries introduced such a tax, there would be no distortion to competition between multinationals in purchasing assets. However, note that Samuelson's depreciation allowance is required for this to be true, contrary to the claim made by Slemrod (1995).

\section{F. Equilibrium of the Model}

To solve the model, we first define combinations of strategies as $(i, j)$, where $i$ is the choice of the home firm and $j$ is the choice of the foreign firm. Conditional on the choice made by one firm, the other firm will choose its strategy to generate the highest post-tax profit. Using the values in Table 2, this can be expressed in terms of the size of the fixed cost, $F$. First, we economize on parameters by defining some summary terms. Let:

\footnotetext{
${ }^{14}$ For this reason, in their empirical formulation of the EATR, Devereux and Griffith (1998a) scale the difference between pre-tax and post-tax value by the pre-tax net present value gross of the fixed cost, $F$.
} 


$$
\begin{aligned}
& \varphi_{1}=s[a-s-m(2-\eta)] \\
& \varphi_{2}=s[a-m(2-\gamma)] \\
& \varphi_{3}=s(a-s)+m[a(\gamma-\eta)+s(1-2 \gamma)+m\{\eta(\eta-1)-\gamma(\gamma-1)\}] \\
& \varphi_{4}=a s+m[a(\gamma-\eta)+s(1-\gamma-\eta)+m\{\eta(\eta-1)-\gamma(\gamma-1)\}]
\end{aligned}
$$

We can then set out the best responses of each agent as follows:

\begin{tabular}{|c|cc|}
\hline $\begin{array}{l}\text { Then home } \\
\text { firm chooses: }\end{array}$ & $\mathrm{B}$ & $\mathrm{C}$ \\
\hline B iff: & $F>\frac{4}{9 b \hat{\eta}} \varphi_{4}$ & $F>\frac{4}{9 b \hat{\eta}} \varphi_{3}$ \\
\hline $\begin{array}{l}\text { Then foreign } \\
\text { firm chooses: }\end{array}$ & $\mathrm{B}$ & If home firm chooses: \\
\hline B iff: & $F>\frac{4}{9 b} \varphi_{2}$ & $\mathrm{C}$ \\
& & $F>\frac{4}{9 b} \varphi_{1}$ \\
\hline
\end{tabular}

To interpret these conditions, it is useful to begin with the case of no tax, which is equivalent in strategic terms to setting $\gamma=\eta=\hat{\eta}=1$. This implies that

$$
\begin{aligned}
& \widetilde{\varphi}_{1}=\widetilde{\varphi}_{3}=a-s-m, \text { and } \\
& \widetilde{\varphi}_{2}=\widetilde{\varphi}_{4}=a-m .
\end{aligned}
$$

That is, the cut-off points are the same for both firms. That is, for values of the fixed cost $F$ above $4 \widetilde{\varphi}_{2} / 9 b$, both firms would choose strategy B. We denote this pair of strategic choices as $(\mathrm{B}, \mathrm{B})$ where the first element indicates the choice of the home firm and the second the choice of the foreign firm. Conversely, for values of $F$ below $4 \widetilde{\varphi}_{1} / 9 b$, both firms would choose strategy $\mathrm{C}-$ i.e., $(\mathrm{C}, \mathrm{C})$. For values of $F$ such that $4 \widetilde{\varphi}_{1} / 9 b<F<4 \widetilde{\varphi}_{2} / 9 b$, one firm would choose strategy B and the other strategy C. This implies two possible outcomes, (B,C) and (C,B). 
Next consider the case of an arbitrary value of the home depreciation allowances, $A<t$, such that $\gamma>1$. However, suppose that outbound investment is taxed on a cash flow basis, so that $\eta=\hat{\eta}=1$. In this case, the values of the cut-off points become:

$$
\begin{aligned}
& \overline{\varphi_{1}}=s[a-s-m] \\
& \overline{\varphi_{2}}=s[a-m(2-\gamma)] \\
& \overline{\varphi_{3}}=s(a-s)+m[(a-m \gamma)(\gamma-1)+s(1-2 \gamma)] \\
& \overline{\varphi_{4}}=a s+m[(a-m \gamma)(\gamma-1)-s \gamma] .
\end{aligned}
$$

It is straightforward to show that $\bar{\varphi}_{2}>\bar{\varphi}_{1}, \bar{\varphi}_{4}>\bar{\varphi}_{2}$, and $\bar{\varphi}_{3}>\bar{\varphi}_{1}$, which introduces new strategic combinations. For example, values of $F$ such that $4 \bar{\varphi}_{1} / 9 b<F<4 \bar{\varphi}_{3} / 9 b$ and $4 \bar{\varphi} / 9 b<F<4 \bar{\varphi}_{4} / 9 b$ would result in the pair of strategic choices $(\mathrm{C}, \mathrm{B})$.

Finally, for the same arbitrary value of $\gamma>1$ we can consider how the cut-off points change as the tax treatment of outbound investment becomes less generous -- as $\eta$ increases. $\bar{\varphi}_{2}$ is unaffected by changes in $\eta$; this determines the strategic choice of the foreign firm conditional on the home firm choosing strategy $\mathrm{B}$, and is therefore unaffected by the tax treatment of its outbound investment. However, $\overline{\varphi_{1}}$ is increasing in $\eta$ : conditional on the home firm choosing $C$, a higher $\eta$; implies that the home firm will choose lower output which makes it more likely that the foreign firm chooses $\mathrm{C}$. By contrast, $\bar{\varphi}_{2}$ and $\bar{\varphi}_{4}$ are both decreasing in $\eta$. That is, whichever strategy chosen by the foreign firm, a higher $\eta$ will reduce the post-tax profits of $\mathrm{C}$ for the home firm, and therefore make it more likely that that the home firm will choose B.

These strategic choices are summarized in Figure 1 for a range of values of $\eta \geq 1$. Note that $\varphi_{1}=\varphi_{2}$ and $\varphi_{3}=\varphi_{4}$ at $\eta=\gamma+s / m$. As $\eta$ increases above 1 , the home firm becomes less likely to produce abroad, which reduces the size of the $(\mathrm{C}, \mathrm{B})$ regions, but increases the size of the $(B, C)$ regions. 


\section{G. Welfare Implications}

Given the definition of welfare above, it can be summarized under each combination of strategies as follows:

\section{Summary of Welfare in Simplified Model}

\begin{tabular}{|c|c|c|}
\hline \multirow{2}{*}{ Home Firm } & \multicolumn{2}{|c|}{ Foreign Firm Chooses } \\
\cline { 2 - 3 } & $\mathrm{B}$ & $\mathrm{C}$ \\
\hline $\mathrm{B}$ & $W_{B B}=\left\{b X_{B B}+(\gamma-1) m\right\} X_{B B}$ & $W_{B C}=\left\{b X_{B C}+(\gamma-1) m\right\} X_{B C}$ \\
\hline $\mathrm{C}$ & $W_{C B}=\left\{b X_{C B}+(\eta-1) m\right\} X_{C B}-F$ & $W_{C C}=\left\{b X_{C C}+(\eta-1) m\right\} X_{C C}-F$ \\
\hline
\end{tabular}

Given these expressions, it is possible to identify the welfare-maximizing regime for alternative values of $F$, conditional on the choice of the foreign firm. To do this, it is useful to define two new parameters:

$$
\begin{aligned}
& \chi_{3}=\frac{m}{3 b}\left\{a(\eta-\gamma)+2 s(\boldsymbol{\gamma}-1)+m\left\{3(\eta-\gamma)-2\left(\eta^{2}-\gamma^{2}\right)\right\}\right\} \\
& \chi_{4}=\frac{m}{3 b}\left\{a(\eta-\gamma)+s(\boldsymbol{\gamma}+\eta-2)+m\left\{3(\eta-\gamma)-2\left(\eta^{2}-\boldsymbol{\gamma}^{2}\right)\right\}\right\}
\end{aligned}
$$

Using these parameters, welfare is highest if and only if the home firm chooses its strategy in the following way:

\begin{tabular}{|c|cc|}
\hline $\begin{array}{l}\text { Then home } \\
\text { firm chooses: }\end{array}$ & If foreign firm chooses: \\
\hline B iff: & $F>\frac{4}{9 b} \varphi_{4}+\chi_{4}$ & $\mathrm{C}$ \\
\hline
\end{tabular}

These critical values of $F$ are similar to the private critical values for the home firm. There are two differences, however. First, the firm's critical value is divided by the tax parameter $\hat{\eta}$. Second, each critical value has an additional term: one of the 
parameters defined in (11). Given these critical values and $\hat{\eta}=1$, welfare is maximized if $\chi_{3}=\chi_{4}=0$; that is, where the choice of the home firm is that required for maximizing welfare. Exploring the properties of these two parameters yields a number of observations.

1. The only fully optimal tax system is $\gamma=\eta=1$-- i.e., a cash flow tax or equivalent for both domestic and outbound investment. $\gamma=\eta=1$ implies $\chi_{3}=\chi_{4}=0$. This is not surprising; a cash flow tax generates a zero effective marginal tax rate and an effective average tax rate of $t$. Because all investment is treated in the same way, the tax does not distort either the strategic choice or the level of investment conditional on each strategic choice. However, there are two other implications of this observation.

2. Setting $\gamma=\eta>1--$ i.e., a residence based tax on accrual --results in the home firm's choosing strategy $B$ for more values of $F$ than is optimal, and hence reduces welfare relative to no tax or relative to a cash flow tax for both domestic and outbound investment. $\quad \gamma=\eta>1$ implies $\tilde{\chi}_{3}>0$ and $\tilde{\chi}_{4}>0$. Because both of these values are positive, the critical values of $F$ for maximizing welfare are higher than those for maximizing profit. Values of $\hat{\eta}>1$ would increase the difference between the two sets of critical values. This implies that for a range of values of $F$, the home firm will choose strategy B when welfare would be higher if it chose strategy C.

3. Setting $\gamma>1$ and $\eta=1$-- i.e., a standard corporation tax for domestic investment and, in effect, a cash flow tax for outbound investment -- results in the home firm's choosing strategy $C$ for more values of $F$ than is optimal, and hence reduces welfare relative to no tax or a relative to cash flow tax for both domestic and outbound investment. $\eta=1$ and $\gamma>1$ implies $\tilde{\chi}_{3}<0$ and $\tilde{\chi}_{4}<0$. Recall also that in this case $\hat{\eta}=1$. 
Hence the critical values of $F$ for maximizing welfare are lower than those for maximizing profit. This implies that, for a range of values of $F$, the home firm would choose strategy C when strategy B would be optimal.

These last two observations imply that, conditional on $\gamma>1$ and on the strategic choice of the foreign firm, the optimal choice of $\eta$ would be between 1 and $\gamma$. However, as the first observation implies, this optimal choice of $\eta$ depends on the strategic choice of the foreign firm. If the foreign firm chooses B, the government could choose a value of $\eta$ to set $\chi_{4}=0$; if the foreign firm chooses $C$, the government could choose a value of $\eta$ to set $\chi_{3}=0$. These require different values of $\eta$.

Further, even if the government could accomplish this, the choice of $\eta$ will not be consistent with the value which, conditional on the strategic choice of the home firm, induces the optimal level of investment. For example, suppose that we are in regime $(\mathrm{C}, \mathrm{C})$. Then, conditional on this regime, the optimal choice of $\eta$ is given by solving $\partial W_{c c} / \partial \eta=0$, which results in the optimal value being $\eta=(5 m-a) / 4 m$. The equivalent value for regime $(\mathrm{C}, \mathrm{B})$ is $\eta=(5 m-a-s) / 4 m$.

To summarize, only a cash flow tax or equivalent for both domestic and outbound investment would result in welfare-maximizing choices by home firm. If the domestic tax system is such that $A<t$, as is commonly the case, then there is no way of taxing outbound investment which does not distort at least one strategic choice; even if this were avoided, there will remain a distortion to the level of investment undertaken.

In the next section, we compare the performance of the principal tax systems observed in practice and advocated in the literature, in the more realistic setting in which the foreign country taxes activity taking place within its jurisdiction. We also generalize the model to allow for differentiated goods. 


\section{TAX POLICY IN A MORE GENERAL MODEL}

The most important simplification of the model in the previous section is that it assumed that tax is levied only in the home country. While this permits a simple analysis of the strategic choices facing each firm -- and of the role of the home tax in affecting those choices -- foreign taxation is a significant factor in determining home welfare. The reason is straightforward: if the foreign country captures part of the economic rent generated by the home firm, then that part of the economic rent does not accrue to domestic residents and therefore cannot contribute to welfare.

In this section, we therefore investigate a more general model by including tax outside the home country, $H$. To avoid the introduction of the foreign tax having a direct effect on the strategic choice of the foreign firm, we assume that the same tax is levied on profits from all production of the foreign firm, irrespective of where its production takes place.

In this section, we begin by describing the tax systems, and hence the values of post-tax profit and welfare, in more detail. We then proceed in the same way as in section II. First, we find the optimal levels of output and the corresponding levels of profit of each firm conditional on each possible combination of strategic choices $(i, j)$. Then, to solve for the equilibrium outcome of the game between the two firms, we evaluate strategies first from the foreign firm's perspective and then from the home firm's perspective. We again simplify the model by assuming that at least one of strategy B and $\mathrm{C}$ yields a positive post-tax profit for each firm. This means that we can rule out strategy A entirely, again leaving only four possible combinations.

However, we now introduce differentiated products, such that $\mathrm{X}$ and $\mathrm{Y}$ are no longer perfect substitutes. The inverse demand equations therefore now become 


$$
p_{i j}=a-b X_{i j}-c Y_{i j},
$$

and

$$
q_{i j}=a-b Y_{i j}-c X_{i j},
$$

where $p_{i j}$ is the price of $X_{i j}$ and $q_{i j}$ is the price of $Y_{i j}$, for all pairs of strategies $i$ and $j$.

\section{A. Forms of Taxation}

As before, we analyze standard corporation taxes in each location. The domestic tax system and the post-tax value of the investment under strategy B for the home firm is exactly as described in section II. However, it is now necessary to consider the interaction of the tax treatment by the home country, $H$, of income derived from outbound investment, and the tax treatment of the foreign country, $G$, of the same income. In the presence of taxation in all countries, the total tax paid by the home firm is given by:

$$
T_{i j}=t \pi_{i j}+t^{*} \pi_{i j}^{a}+\sigma^{*} D_{i j}^{a},
$$

where $\pi_{i j}$ and $\pi_{i j}^{a}$ represent taxable profits in $H$ and in $G$ for strategies $(i, j)$, and $t^{*}$ and $\sigma^{*}$ represent overall tax rates on, respectively, taxable profits in $G$ and dividends ( $D_{i j}^{a}$ ) paid by the foreign affiliate to the parent. These overall tax rates depend both on the tax system in $G$ and the treatment of the foreign source income by $H$.

The parameters $t^{*}$ and $\sigma^{*}$ depend on the tax system. For example, with deferral, the home country does not tax the taxable profit arising in the foreign country; hence $t^{*}=$ $t^{a}$, the statutory tax rate in the foreign country. Similarly, in the absence of deferral, there is no additional tax on repatriation of dividends, so that $\sigma^{*}=0$. These and the other parameters are summarized in the following table for the combinations of deferral and non-deferral, and limited credit and deduction systems. 


\section{Deferral}

\begin{tabular}{|c|c|}
\hline Limited credit & Deduction \\
\hline$t^{*}=t^{a}$ & $t^{*}=t^{a}$ \\
\hline$\sigma^{*}=\max \left\{\frac{t-t^{a}}{1-t^{a}}, 0\right\}$ & $\sigma^{*}=t$ \\
\hline
\end{tabular}

\section{Non-deferral}

\begin{tabular}{|c|c|}
\hline Limited credit & Deduction \\
\hline$t^{*}=\max \left\{t, t^{a}\right\}$ & $t^{*}=t^{a}+t\left(1-t^{a}\right)$ \\
\hline$\sigma^{*}=0$ & $\sigma^{*}=0$ \\
\hline
\end{tabular}

These parameters can be translated into the parameters representing the overall tax on outbound investment. To do this, consider a foreign investment by the home firm, with initial cost of $F^{\prime}+K^{\prime}{ }_{C j}$, so that $F+K_{C j}=F+m X_{C j}$ represents the cost in secondperiod terms, as in the previous section. In this section, we make the assumption that the fixed cost, $F$, is treated as capital expenditure by all the tax systems. In the presence of the tax this investment generates a reduction in taxable profit of $\hat{A}^{a}\left(F^{\prime}+K^{\prime}{ }_{C j}\right)$, where $\hat{A}^{a}$ is the depreciation allowance per unit of investment in $G$. If the investment is financed by new equity, then the net cost reflects this reduction in taxable profit, multiplied by the tax rate, $t^{*}$. If the investment is financed by retained earnings in the subsidiary, then dividends fall by the cost of the investment, and there is an additional reduction in the tax on dividends at rate $\sigma^{*}$. Combining these effects and defining $A^{*}=t^{*} \hat{A}^{a}$, the net cost of the investment is given by: 


\begin{tabular}{|c|c|}
\hline Retained earnings & New equity \\
\hline$\left(1-\sigma^{*}\right)\left(1-A^{*}\right) \frac{F+m X_{c j}}{1+r}$ & $\left(1-A^{*}\right) \frac{F+m X_{c j}}{1+r}$ \\
\hline
\end{tabular}

The income generated in the second period is $p_{c j} X_{c j}$, which we assume is paid to the parent. In the case of the investment being financed by retained earnings, it is paid as a dividend, and therefore incurs tax at rate $t^{*}$ and again at rate $\sigma^{*}$. If the investment is financed by new equity, then it is assumed that the initial capital invested can be repaid to the parent without incurring the tax on dividends. Hence the net return in each case is:

\begin{tabular}{|c|l|}
\hline Retained earnings & \multicolumn{1}{|c|}{ New equity } \\
\hline$\left(1-\sigma^{*}\right)\left(1-t^{*}\right) p_{c j} X_{c j}$ & $\left(1-t^{*}\right) p_{c j} X_{c j}$ \\
& $-\sigma^{*}\left\{\left(1-t^{*}\right) p_{c j} X_{c j}-\left(1-A^{*}\right) \frac{F+m X_{c j}}{1+r}\right\}$ \\
\hline
\end{tabular}

The value to the parent firm of each type of investment is simply the net income less the net cost. We can summarize this value as:

$$
\begin{aligned}
V_{c j} & =(1-\lambda)\left(1-A^{*}\right) F+\left(1-\sigma^{*}\right)\left(1-t^{*}\right)\left[p_{c j}-\eta m\right] X_{c j} \\
& =\left(1-\sigma^{*}\right)\left(1-t^{*}\right)\left\{\left[p_{c j}-\eta m\right] X_{C j}-\eta F\right\},
\end{aligned}
$$

where $\eta$ is now defined as

$$
\eta=\frac{(1-\lambda)\left(1-A^{*}\right)}{\left(1-\sigma^{*}\right)\left(1-t^{*}\right)}
$$

and $\lambda=\sigma^{*}$ for the case of investment financed by retained earnings, and $\lambda=\sigma^{*} /(1+r)$ for the case of investment financed by new equity.

The taxes faced by the foreign firm are straightforward. We make the simplifying assumption that the tax systems in the other two countries -- where the other firm is resident and where the market is located -- are identical. We also assume that the former 
does not operate a deduction system. This implies that the foreign firm faces the same tax system irrespective of its choice of location of production. Specifically, if it produces at home, its post-tax profit is:

$$
Z_{i B}=\left(1-t^{a}\right)\left[q_{i B}-s-\gamma^{a} m\right] Y_{i B},
$$

where $q_{i B}$ is the price of its final $\operatorname{good} Y$, and $A^{a}=t^{a} \hat{A}^{a}$ and

$$
\gamma^{a}=\frac{\left(1-A^{a}\right)}{\left(1-t^{a}\right)}
$$

If it produces abroad, the value of its investment is

$$
Z_{i C}=\left(1-A^{a}\right) F+\left(1-t^{a}\right)\left[q_{i C}-\gamma^{a} m\right] Y_{i C} .
$$

The levels of post-tax profit from each strategic choice of the home firm are therefore given in (3a) for strategy B and (13) for strategy C. The corresponding expressions for the foreign firm are given in (15) and (16).

\section{B. Determining Output and Profit for Each Combination of Strategies}

The profit-maximizing output levels corresponding to each strategy are shown in Table 3, which are derived from each firm choosing its output level to maximize profit, conditional on both firms having chosen their strategy.

These output levels are similar to those of the simplified model. However, in each case there is an additional term, reflecting the impact of the combined tax system. Note that in the special case of $\gamma^{a}=1$, and $b=c$ (and hence $b d=s$ ), we return to the values in the simplified model of Table 1. Apart from allowing $b$ to differ from $c$, the additional terms in Table 3 reflect the role of the foreign tax system, summarized by $A^{a}$ and hence $\gamma^{a}$. Thus, conditional on the strategic choice, lower depreciation allowances in the 
foreign country raise $\gamma^{a}$ and increase output of the home firm and reduce output of the foreign firm.

TABLE 3

Summary of Output Levels of Home and Foreign Firm in General Model

\begin{tabular}{|c|c|c|}
\hline \multirow{2}{*}{$\begin{array}{c}\text { Home firm } \\
\text { Chooses }\end{array}$} & \multicolumn{2}{|c|}{ Foreign firm chooses } \\
\hline & B & $\mathrm{C}$ \\
\hline $\mathrm{B}$ & $\begin{aligned} X_{B B} & =\frac{a-s-m}{2 b+c} \\
& +\frac{\left[c\left(\gamma^{a}-1\right)-2 b(\gamma-1)\right] m}{4 b^{2}-c^{2}} \\
Y_{B B}= & \frac{a-s-m}{2 b+c} \\
& +\frac{\left[c(\gamma-1)-2 b\left(\gamma^{a}-1\right)\right] m}{4 b^{2}-c^{2}}\end{aligned}$ & $\begin{aligned} X_{B C} & =\frac{a-m-2 b d}{2 b+c} \\
& +\frac{\left[c\left(\gamma^{a}-1\right)-2 b(\gamma-1)\right] m}{4 b^{2}-c^{2}} \\
Y_{B C} & =\frac{a-m+c d}{2 b+c} \\
& +\frac{\left[c(\gamma-1)-2 b\left(\gamma^{a}-1\right)\right] m}{4 b^{2}-c^{2}}\end{aligned}$ \\
\hline $\mathrm{C}$ & $\begin{aligned} X_{C B} & =\frac{a-m+c d}{2 b+c} \\
& +\frac{\left[c\left(\gamma^{a}-1\right)-2 b(\eta-1)\right] m}{4 b^{2}-c^{2}} \\
Y_{C B} & =\frac{a-m-2 b d}{2 b+c} \\
& +\frac{\left[c(\eta-1)-2 b\left(\gamma^{a}-1\right)\right] m}{4 b^{2}-c^{2}}\end{aligned}$ & $\begin{aligned} X_{C C} & =\frac{a-m}{2 b+c} \\
& +\frac{\left[c\left(\gamma^{a}-1\right)-2 b(\eta-1)\right] m}{4 b^{2}-c^{2}} \\
Y_{C C} & =\frac{a-m}{2 b+c} \\
& +\frac{\left[c(\eta-1)-2 b\left(\gamma^{a}-1\right)\right] m}{4 b^{2}-c^{2}}\end{aligned}$ \\
\hline
\end{tabular}

These output levels can again be substituted back into the expressions for the profit for each combination. The resulting post-tax profit for each firm under each combination of strategies is presented in Table 4. The structure of these expressions is related to that in Table 2 with two significant changes. First, the foreign firm post-tax profit is now lower, relative to its output, because it now pays tax on its activities. 
Second, the parameters of the tax system now reflect the more general tax treatment.

TABLE 4

Profit Levels for the Home and Foreign Firm in the General Model

\begin{tabular}{|c|c|c|}
\hline \multirow{2}{*}{$\begin{array}{c}\text { Home firm } \\
\text { chooses }\end{array}$} & \multicolumn{2}{|c|}{ Foreign Firm Chooses } \\
\cline { 2 - 3 } & $\mathrm{B}$ & $\mathrm{C}$ \\
\hline \multirow{2}{*}{$\mathrm{B}$} & $V_{B B}=(1-t) b X_{B B}^{2}$ & $V_{B C}=(1-t) b X_{B C}^{2}$ \\
\hline \multirow{2}{*}{$\mathrm{C}$} & $Z_{B B}=\left(1-t^{a}\right) b Y_{B B}^{2}$ & $Z_{B C}=\left(1-t^{a}\right)\left\{b Y_{B C}^{2}-\gamma^{a} F\right\}$ \\
& $V_{C B}=\left(1-\sigma^{*}\right)\left(1-t^{*}\right)\left\{b X_{C B}^{2}-\eta F\right\}$ & $V_{C C}=\left(1-\sigma^{*}\right)\left\{1-t^{*}\right)\left\{b X_{C C}^{2}-\eta F\right\}$ \\
& $Z_{C B}=\left(1-t^{a}\right) b Y_{C B}^{2}$ & $Z_{C C}=\left(1-t^{a}\right)\left\{b Y_{C C}^{2}-\gamma^{a} F\right\}$ \\
\hline
\end{tabular}

Given the expressions in Tables 3 and 4, we can again analyze the critical values of $F$ which determines the strategic choice made by each firm conditional on a given choice by the other firm. We then identify which combinations of strategic choices will occur for given values of $F$ and the home tax system; we again summarize the home tax system as it applies to outbound investment by $\eta$. Finally, we analyze the welfare properties of alternative tax systems.

\section{Equilibrium of the Model}

In solving the model, we again make use the parameters summarized in (19). However, it is also useful to define some further terms.

\section{Strategic Choices by the Foreign Firm}

We begin by analyzing the choices of the foreign firm. If the home firm chooses $\mathrm{B}$, the foreign firm will choose $\mathrm{C}$ if and only if $Z_{B C}>Z_{B B}$; that is:

$$
F<\varphi_{2}^{*}=\frac{b\left(Y_{C B}^{2}-Y_{B B}^{2}\right)}{\gamma^{a}} .
$$


Similarly, if the home firm chooses $\mathrm{C}$, then the foreign firm will choose $\mathrm{C}$ if and only if $Z_{C C}>Z_{B C}$; that is:

$$
F<\varphi_{1}^{*}=\frac{b\left(Y_{C C}^{2}-Y_{B C}^{2}\right)}{\gamma^{a}},
$$

where $\varphi_{1}^{*}$ and $\varphi_{2}^{*}$ are defined in the Appendix.

These conditions have close similarities to the simplified case we presented in section II. Hence the comments made there -- especially in relation to the importance of the tax parameter on outbound investment by the home firm, $\eta$-- continue to hold. Compared with the critical values in that case however, these critical values have two further elements reflecting the foreign tax system. First, each is divided by $\gamma^{a}$. As allowances in the foreign tax become more generous, $A^{a}$ increases and $\gamma^{a}$ falls (since $\gamma^{a}=$ $\left.\left(1-A^{a}\right) /\left(1-\tau^{a}\right)\right)$. Because the fixed cost of investing abroad is assumed to receive an allowance of $A^{a}$, the higher is $A^{a}$ (and hence the lower is $\gamma^{a}$ ), the more likely the foreign firm is to choose C. Second, the critical values of both $\varphi_{1}^{*}$ and $\varphi_{2}^{*}$ include an additional term reflecting again the generosity of the foreign tax system, again measured by $\gamma^{a}$. This addition reflects the impact of $\gamma^{a}$ on the profit-maximizing level of output conditional on a chosen strategy, as discussed in the context of Table 3.

The critical values of $F$ are illustrated in Figure 2, which plots $\varphi_{1}^{*}$ and $\varphi_{2}^{*}$ against $\eta$. As with $\varphi_{2}$ in section II, $\varphi_{2}^{*}$ does not depend on $\eta$, so that it is represented by a vertical segment. The impact of the foreign tax system is to move it to the right of $\varphi_{2}$. Again, as in the case of $\varphi_{1}$ in section II, $\varphi_{1}^{*}$ increases with $\eta$. 


\section{Strategic Choices by the Home Firm}

The strategic choices of the home firm can be analyzed in a similar way. Suppose first that the foreign firm chooses strategy B. The home firm then chooses $\mathrm{C}$ if and only if $V_{C B}>V_{B B}$, or :

$$
F<\varphi_{3}^{*}=\frac{b\left(X_{C B}^{2}-R X_{B B}^{2}\right)}{\eta},
$$

where $R$ reflects the tax rate on domestic investment relative to the tax on outbound investment:

$$
R=(1-t) /\left(\left(1-\sigma^{*}\right)\left(1-t^{*}\right) .\right.
$$

If instead the foreign firm chooses strategy $\mathrm{C}$, the home firm will choose strategy $\mathrm{C}$ if and only if $V_{C C}>V_{B C}$, or:

$$
F<\varphi_{4}^{*}=\frac{b\left(X_{C C}^{2}-R X_{B C}^{2}\right)}{\eta} .
$$

Again, the definitions of $\varphi_{3}^{*}$ and $\varphi_{4}^{*}$ are given in the Appendix.

While the expressions for critical values $\varphi_{3}^{*}$ and $\varphi_{4}^{*}$ are somewhat forbidding, they have the same structure as the critical values for the foreign firm, $\varphi_{1}^{*}$ and $\varphi_{2}^{*}$. As with the critical values in section II, both are divided by $\eta \cdot{ }^{15}$ As $\eta$ increases, both $\varphi_{3}^{*}$ and $\varphi_{4}^{*}$ fall. This makes it more likely that the home firm would choose strategy B rather than strategy C. This is because the fixed cost receives an allowance, reflected in $\eta$.

There are additional terms reflecting the relative tax treatment of the home and foreign firms. These are more complex than in the case of the foreign firm because the home firm faces a more complex tax treatment. However, it is straightforward to show

\footnotetext{
15 in section II, this was $\hat{\eta}$, reflecting the possibility that the fixed cost might be deductible whatever the depreciation allowance.
} 
that both $\varphi_{3}^{*}$ and $\varphi_{4}^{*}$ fall as $\eta$ increases - implying that the home firm is less likely to choose strategy $C$. It is also possible to show that $\varphi_{4}^{*}$ always lies to the right of $\varphi_{3}^{*}$; that is, the critical value of $F$ for the home firm in choosing strategy $\mathrm{C}$ over strategy B is lower if the foreign firm chooses strategy $\mathrm{C}$.

We also summarize these values in Figure 2. The Nash equilibria follow a similar pattern to Figure 1 . Thus, at low levels of $F$, there is a $(\mathrm{C}, \mathrm{C})$ Nash equilibrium, while at high levels of $F$, there is a $(\mathrm{B}, \mathrm{B})$ Nash equilibrium. However, as before, the tax treatment of outbound investment, summarized by $\eta$, has important effects on the Nash equilibria. As before, there are two (C,B) regions which would not exist in the absence of tax, and also a much larger $(B, C)$ region which also would not exist in the absence of the tax.

\section{Measuring Welfare and Implications for Tax Policy}

In the presence of foreign taxation, we define welfare to be the income accruing to residents of the home country, that is the pre-tax income of domestic investment plus the post-foreign-tax income from outbound investment. Following this approach, the welfare under each pair of strategic choices in the more general model is shown below.

Using the definitions of output for each combinations of strategies, it is straightforward to show that $X_{\mathrm{CB}}>X_{\mathrm{CC}}$ and that $X_{\mathrm{BB}}>X_{\mathrm{BC}}$. It follows, then, that $W_{\mathrm{CB}}>$ $W_{\mathrm{CC}}$ and $W_{\mathrm{BB}}>W_{\mathrm{BC}}$. Hence any given strategy for the home firm is more profitable if the foreign firm chooses B instead of C. However, it is not possible to make other comparisons between these levels of welfare without more specific definitions of the tax system -particularly the treatment of outbound investment, summarized by $\eta$. 


\section{Summary of Welfare for Each Strategic Choice}

\begin{tabular}{|c|c|c|}
\hline Home Firm & \multicolumn{2}{|c|}{ Foreign Firm Chooses } \\
\hline Chooses & B & $\mathrm{C}$ \\
\hline B & $W_{B B}=\left[b X_{B B}+(\gamma-1) m\right] X_{B B}$ & $W_{B C}=\left[b X_{B C}+(\gamma-1) m\right] X_{B C}$ \\
\hline $\mathrm{C}$ & $\begin{aligned} W_{C B}= & -\left(1-A^{a}\right)\left[F+m X_{C B}\right] \\
& +\left(1-t^{a}\right)\left[b X_{C B}+(\eta-1) m\right] X_{C B}\end{aligned}$ & $\begin{aligned} W_{C C}= & -\left(1-A^{a}\right)\left[F+m X_{C C}\right] \\
& +\left(1-t^{a}\right)\left[b X_{C C}+(\eta-1) m\right] X_{C C}\end{aligned}$ \\
\hline
\end{tabular}

National welfare depends on both the tax regime and the fixed cost of investing abroad, $F$, which, together with the other parameters of the model, determine the strategic choices made by each firm. Because we are primarily concerned with the tax treatment of outbound investment by the home firm, we could, in principle, analyze optimal tax policy by computing the level of welfare corresponding to all possible combinations of $F$ and $\eta$, given other parameters and other elements of the tax system, and taking into account the impact on the strategic choice and the level of investment conditional on the strategic choice. This would yield an optimal rate of $\eta$ corresponding to each value of $F$.

We do not follow this approach for two reasons. First, the model is too intractable to derive such simple optimal values. Second, in any case, even if such optimal values could be found, they would be of little use to policymakers, who must create general tax systems which apply to a range of values of $F$, if not all values of $F$. Instead of presenting analytical results, we therefore rely on a simulation model to examine specific alternative tax regimes. For given values of the parameters, the model can find the measure of welfare for each tax regime for any value of $F$. In particular, we are interested in comparing welfare levels under two specific regimes. The first is the 
regime proposed by Feldstein and Hartman (1979) -- deduction without deferral. The second is a regime commonly used in practice -- limited credit with deferral. ${ }^{16}$

The extent to which the foreign government captures part of the pre-tax economic rent affects national welfare because welfare for the home country is calculated net of foreign taxes. Ignoring foreign tax, the pre-tax economic rent is generally higher if the home firm undertakes more outbound investment, and outbound investment is generally encouraged by use of the deferral system. However, given outbound investment, a higher foreign tax rate generally implies lower national welfare. As a result, the optimal tax policy now involves balancing the need not to discriminate against outbound investment by the home firm against the transfer of welfare to the foreign government. In order to analyze this balance, we present three sets of results, corresponding to different foreign tax rates.

\section{No Foreign Tax}

Figure 3 presents the case of no foreign tax: $t^{a}=0 \cdot{ }^{17}$ This is essentially the case we analyzed in section II; in fact, setting $b=c$ exactly reproduces the model in section II. Here there is no transfer of welfare to the foreign government. Further, because there is no foreign tax, there is also no distinction between the limited credit and deduction methods of taxing foreign income. However, there remains a distinction between taxing on deferral and on accrual. In Figure 3, the unbroken line represents welfare in the case of deferral, and the dotted line represents welfare in the case of accrual taxation. The parameter values are given above the figure: the home tax system is represented by $t=$

\footnotetext{
${ }^{16}$ No OECD country attempts to tax active corporate income without deferral, and no country permits only a deduction for foreign taxes paid, although some countries have an exemption system rather than a limited credit system.
} 
0.5 and $A=0.4$. We find a similar picture for a wide range of parameters of both the tax system and demand and cost factors.

The Figure indicates - as we also show in Figures 1 and 2 - that for low values of $F$, combination $(\mathrm{C}, \mathrm{C})$ prevails for both $\eta=\gamma$ (accrual taxation) and $\eta=1$ (deferral).

Welfare is higher under deferral because output and profit are higher than under accrual taxation. This difference represents the standard case of the impact of tax on the cost of capital and hence output. In the absence of strategic choices, a standard corporation tax results in lower output, profit, and welfare. A cash flow tax avoids this affect. However, this effect is dominated by the impact of tax on the strategic choice.

As $F$ rises the combination of strategic choices changes. This occurs first under the accrual tax, with a shift from $(\mathrm{C}, \mathrm{C})$ to $(\mathrm{B}, \mathrm{C})$; that is, the home firm switches to home production. This creates a decline in welfare under the accrual tax and a greater advantage of deferral (because pre-tax economic rent remains higher in the $(C, C)$ combination). This advantage is increased for still higher values of $F$, as the more favorable treatment of outbound investment compared with domestic investment induces the home firm to maintain its outbound investment for higher values of $F$, inducing the still more favorable $(\mathrm{C}, \mathrm{B})$ regime. This is subsequently reduced as the possibility also arises of the $(\mathrm{B}, \mathrm{C})$ regime. (In this case we measure welfare as the mean of welfare in the two possible regimes).

There is only one range of values of $F$ for which the accrual tax generates higher welfare than under deferral. That corresponds with a high $F$. In the absence of taxation, both firms would choose strategy B. With tax and deferral, however, the tax advantage to outbound investment induces the home firm to choose strategy C (creating a (C, B) combination) when welfare would be higher from strategy $B(a(B, B)$ combination).

\footnotetext{
${ }^{17}$ In the case of accrual taxation, we assume that the home government uses $A$, rather
} 
Beyond this range, the costs of outbound investment are so high that they outweigh any tax advantage, and both firms choose strategy B. Overall, then, in the absence of foreign taxes, national welfare is higher under deferral than under accrual taxation for almost all possible values of the fixed cost of investing abroad.

\section{Low Foreign Tax Rate}

Figure 4 explores the case of a foreign tax with a relatively low rate: $t^{a}=0.2$ and $A^{a}=0.16$. Because there is foreign taxation, the home government must now choose between the limited credit system and the deduction system. We compare the FeldsteinHartman regime of deduction without deferral (the dashed line) with limited credit with deferral (the dotted line). The regimes represented in Figure 4 are the same as those in Figure 3. For low values of $F$, both firms choose strategy $\mathrm{C}$. In this range, the limited credit system yields slightly higher welfare because output is higher. Under both tax regimes, the foreign government captures part of the economic rent, so that in both cases, welfare of the home country is lower than in Figure 3.

However, under the deduction system, the home firm switches to domestic investment (combination $(\mathrm{B}, \mathrm{C})$ ) at much lower values of $F$, reflecting the very high overall tax rate on outbound investment; there is a smaller drop in welfare moving into this position, reflecting the lower initial welfare. Although the same effect occurs under the limited credit system, the effect is much less pronounced, since the overall tax rate on outbound investment is much lower. There is therefore a much larger range of values of $F$ under which the limited credit system yields a $(\mathrm{C}, \mathrm{C})$ combination and the deduction system yields a $(\mathrm{B}, \mathrm{C})$ combination. Within this range, at higher values of $F$, the latter

yields higher welfare than the former. This ranking is reversed at still higher values of $F$,

than $A^{a}$, to define taxable profit. This implies that, in this case, $\eta=\gamma$. 
however, as the limited credit system induces the $(\mathrm{C}, \mathrm{B})$ combination, which at these tax rates yields a higher welfare for the home country than the $(\mathrm{B}, \mathrm{B})$ combination despite the transfer of welfare to the foreign country. Finally, as in Figure 3, there remains a further $(\mathrm{C}, \mathrm{B})$ area with high values of $F$ under the limited credit system which yields lower welfare than the $(\mathrm{B}, \mathrm{B})$ combination which would occur without tax, and with the deduction system.

Given these tax parameters, then, the choice between the limited credit and the deduction systems is ambiguous, although it remains the case that there is a greater range of values of $F$ for which the limited credit system yields the higher welfare.

\section{High Foreign Tax Rate}

At still higher values of the foreign tax, however, this position is reversed. Figure 5 shows the position for $t^{a}=0.6$ and $A^{a}=0.48$. In this case, because $t<t^{a}$, the limited credit system implies that no tax is collected by the home government on outbound investment; in this case, such investment faces only the foreign tax. However, the deduction system imposes an overall tax rate $\left(t^{a}+t\left(1-t^{a}\right)\right)$ of 80 percent on outbound investment.

The implication of this very high tax rate is that, even for $F=0$, the home firm never chooses strategy $C$. In effect, the $(B, C)$ regime under the deduction system extends to all values of $F$. By contrast, under the limited credit system, there remains an area where the high foreign tax rate does not rule out outbound investment by the home firm. However, in this region under strategy $\mathrm{C}$, the foreign government captures such a large share of the rent that home country welfare is lower than under strategy B. In this case then, by in effect prohibiting outbound investment, the deduction system yields a higher level of welfare. 


\section{SUMMARY AND CONCLUSIONS}

In this paper, we provide a reconsideration of conventional models of taxation of capital income on foreign direct investment which are based on an analysis of marginal investment projects and effective marginal tax rates. We begin with the observation, common in industrial organization research on multinationals economics, that economic rents figure prominently in the strategic choices made by multinational firms.

Accordingly, the roles of rents and strategic choice should be important elements of normative and positive analysis of taxation of foreign-source income.

In the absence of foreign taxation, we find that cash flow taxation of outbound investment generally generates higher national welfare than accrual income taxation. That is, deferral of home-country taxation until earnings on FDI are repatriated is generally superior to including those earnings in current income. This is true even if the home country taxes domestic investment less generously than under a cash flow tax. The reasons lie in the characteristics of outbound investment and the strategic interactions in decisions among multinational companies resident in different countries. We do not impose that total investment (domestic plus outbound) by home firms is fixed. Indeed, conditional on being in a specific regime, the two forms of investment are not substitutes at all.

Our model implies that the tax system should aim at least not to worsen the outcome of the strategic choices made by competing multinationals. That is, if there is a distorting tax on home investment, applying a similar tax to outbound investment would give an advantage to foreign-based multinationals in two ways: the home firm would be more likely to produce at home, and consequently supply less output to the market, and even if the home firm did produce abroad, it would still produce lower output. In both 
cases this can be exploited by the foreign firm to increase its profits at the expense of the home firm, and hence the welfare of the home country. These effects can be reduced or removed by taxing outbound investment on a cash flow, or deferral, basis.

In the presence of foreign taxes, foreign governments capture some of the pre-tax economic rent associated with the home country's outbound foreign direct investment, and so outbound investment provides a smaller benefit to the home country. This narrows the national welfare gain from cash flow taxation of multinational firms' overseas income. If the foreign tax is high enough, it is in the interests of the home country to discourage outbound investment. However, for low rates of foreign tax, a limited credit system with deferral generally dominates a system of accrual taxation with a deduction for foreign taxes paid.

We believe that we have taken an important step toward analyzing guidelines for tax policy toward multinational firms in a framework within which realistic industrial organization plays a significant role. We do not view our model as implying literally that the any country should adopt deferral or some other relatively generous policy toward the taxation of income from outbound foreign direct investment since our model is too stylized to permit such a prescription. Nevertheless, we believe that our emphasis on the industrial organization of multinationals has important implications for the current policy debate over whether U.S. tax policy is excessively generous to outbound foreign direct investment (see the review in Hines, 1999). 


\section{REFERENCES}

Altshuler, Rosanne, Harry Grubert, and T. Scott Newlon. "Has U.S. Investment Abroad Become More Sensitive to Tax Rates?" Working Paper No. 6383, National Bureau of Economic Research, January 1998.

Alworth, Julian. The Finance, Investment, and Taxation Decisions of Multinationals. Oxford: Basil Blackwell, 1998.

Brander, James A. "Strategic Trade Policy." In Gene M. Grossman and Kenneth Rogoff, eds., Handbook of International Economics, volume III. Amsterdam: NorthHolland, 1995.

Brander, James A., and B.J. Spencer. "Export Subsidies and Market Share Rivalry." Journal of International Economics 18 (1985): 83-100.

Bruce, Neil. “Why Are There Foreign Tax Credits?” University of Washington, 1992.

Caves, Richard E. Multinational Enterprise and Economic Analysis, 2nd edition. Cambridge: Cambridge University Press, 1996.

Collins, Julie H., and Douglas A. Shackelford. "Corporate Domicile and Average Effective Tax Rates: The Cases of Canada, Japan, the U.K., and U.S.A.” International Tax and Public Finance 2 (1995): 55-83.

Cummins, Jason G., and R. Glenn Hubbard. "The Tax Sensitivity of Foreign Direct Investment: Evidence from Firm-Level Panel Data." In Martin Feldstein, James R. Hines, Jr., and R. Glenn Hubbard, eds., Effects of Taxation on Multinational Corporations. Chicago: University of Chicago Press, 1995.

Devereux, Michael P., and Rachel Griffith. "The Taxation of Discrete Investment Choices.” Working Paper, Institute for Fiscal Studies, 1998a.

Devereux, Michael P., and Rachel Griffith. "Taxes and the Location of Production: Evidence from a Panel of U.S. Multinationals." Journal of Public Economics 68 (1998b): 335-367.

Devereux, Michael P., and Mark Pearson. "European Tax Harmonization and Production Efficiency." European Economic Review 39 (1995): 1657-1682.

Diamond, Peter, and James Mirrlees. "Optimal Taxation and Public Production: Production Efficiency." American Economic Review 61 (March 1971): 8-27.

Dunning, J.H. International Production and the Multinational Enterprise. London: George Allen and Unwin, 1981.

Dunning, J.H. "Trade, Location of Economic Activity, and MNE: A Search for an Eclectic Approach." In B. Ohlin, P.O. Hesselborn, and P.M. Wijkman, eds., The International Allocation of Economic Activity. London: Macmillan, 1977. 
Feldstein, Martin. "The Effects of Outbound Foreign Direct Investment on the Domestic Capital Stock." In Martin Feldstein, James R. Hines, Jr., and R. Glenn Hubbard, eds., The Effects of Taxation on Multinational Corporations. Chicago: University of Chicago Press, 1995.

Feldstein, Martin, and David Hartman. "The Optimal Taxation of Foreign Source Investment Income.” Quarterly Journal of Economics 93 (November 1979): 613629.

Frisch, Daniel J. "The Economics of International Tax Policy: Some Old and New Approaches." Tax Notes (April 30, 1990): 581-591.

Gordon, Roger H. “Can Capital Income Taxes Survive In Open Economies?” Journal of Finance 47 (1992): 1159-1180.

Grubert, Harry, and John Mutti. "Do Taxes Influence Where U.S. Corporations Invest?" Mimeograph, U.S. Department of the Treasury, 1997.

Grubert, Harry, and John Mutti. "Taxing Multinationals in a World with Portfolio Flows and R\&D: Is Capital Export Neutrality Obsolete?" International Tax and Public Finance (1995): 439-457.

Hartman, David B. "Tax Policy and Foreign Direct Investment in the U.S." National Tax Journal 37 (1984): 475-488.

Haufler, Andreas, and Ian Wooton. "Country Size And Tax Competition For Foreign Direct Investment.” Journal of Public Economics 71 (January 1999): 121-139.

Hines, James R., Jr. "The Case Against Deferral: A Deferential Reconsideration.” National Tax Journal, 1999, forthcoming.

Hines, James R., Jr., and R. Glenn Hubbard. “Appendix.” In Martin Feldstein, James R. Hines, Jr., and R. Glenn Hubbard, eds., The Effects of Taxation on Multinational Corporations. Chicago: University of Chicago Press, 1995.

Horst, Thomas. "A Note on the Optimal Taxation of International Investment Income." Quarterly Journal of Economics 94 (June 1980): 793-798.

Horstmann, I.J., and James R. Markusen. "Endogenous Market Structure and International Trade.” Journal of International Economics 32 (1992): 109-129.

Hufbauer, Gary Clyde. U.S. Taxation of International Income: Blueprint for Reform. Washington, D.C.: Institute for International Economics, 1992.

Janeba, Eckhard. "Foreign Direct Investment Under Oligopoly: Profit Shifting or Profit Capturing?" Journal of Public Economics 60 (June 1996): 423-446.

Joint Committee on Taxation. Factors Affecting the International Competitiveness of the United States. Washington, DC: U.S. Government Printing Office, 1993. 
King, Mervyn A., and Don Fullerton. The Taxation of Income from Capital. Chicago: University of Chicago Press, 1984.

Levinsohn, James, and Joel B. Slemrod. "Taxes, Tariffs, and the Global Corporation." Journal of Public Economics 51 (May 1993): 97-116.

Markusen, James R. "The Boundaries of Multinational Enterprises and the Theory of International Trade." Journal of Economic Perspectives 9 (1995): 169-189.

Motta, Massimo. "Multinational Firms and the Tariff-Jumping Argument: A GameTheoretic Analysis with Some Unconventional Conclusions." European Economic Review 36 (1992): 1557-1572.

Musgrave (Richman), Peggy B. Taxation of Foreign Investment Income: An Economic Analysis. Baltimore: The Johns Hopkins University Press, 1963.

Musgrave, Peggy B. United States Taxation of Foreign Investment Income: Issues and Arguments. Cambridge: International Tax Program, Harvard Law School, 1969.

OECD. Taxing Profits in a Global Economy. Paris: OECD, 1991.

Slemrod, Joel B. "Free Trade Taxation and Protectionist Taxation." International Tax and Public Finance 2 (1995): 471-490.

U.S. Department of the Treasury. A Recommendation for Integration of the Individual and Corporate Tax Systems. Washington, DC: U.S. Government Printing Office, 1992.

U.S. Treasury Department. Blueprints for Basic Tax Reform. Washington, DC: U.S. Government Printing Office, 1977. 


\section{APPENDIX}

\section{Some Definitions in the General Model of Section III}

$\varphi_{1}^{*}=\frac{b}{\gamma^{a}(2 b+c)^{2}}\left\{(a-m)^{2}-(a-m+c d)^{2}+\frac{4 b d m\left[c(\eta-1)-2 b\left(\gamma^{a}-1\right)\right]}{2 b-c}\right\}$

(A.1)

$\varphi_{2}^{*}=\frac{b}{\gamma^{a}(2 b+c)^{2}}\left\{(a-m-2 b d)^{2}-(a-m-s)^{2}+\frac{4 b d m\left[c(\gamma-1)-2 b\left(\gamma^{a}-1\right)\right]}{2 b-c}\right\}$

(A.2)

$\varphi_{3}^{*}=\frac{b}{\eta(2 b+c)^{2}}\left\{\begin{array}{l}(a-m)^{2}-R(a-m-2 b d)^{2}-Q_{4}^{2}\left[(\eta-1)^{2}-R(\gamma-1)^{2}\right] \\ +2 Q_{4}\left[\begin{array}{l}R(a-m-2 b d)(\gamma-1)-(a-m)(\eta-1) \\ +R Q_{3}(\gamma-1)-Q_{3}(\eta-1)\end{array}\right] \\ +2 Q_{3}[(a-m)-R(a-m-2 b d)]\end{array}\right\}$

(A.3)

$\varphi_{4}^{*}=\frac{b}{\eta(2 b+c)^{2}}\left\{\begin{array}{l}(a-m-c d)^{2}-R(a-m-s)^{2}+Q_{3}^{2}(1-R)+Q_{4}^{2}\left[(\eta-1)^{2}-R(\gamma-1)^{2}\right] \\ +2 Q_{3}\left[a-m+c d-Q_{4}(\eta-1)-R\left\{a-m-s-Q_{4}(\gamma-1)\right\}\right] \\ -2 Q_{4}[(\eta-1)(a-m+c d)-R\{(\gamma-1)(a-m-s)\}]\end{array}\right\}$

\section{(A.4)}

where

$$
\begin{aligned}
& Q_{3}=c\left(\gamma^{a}-1\right) m /(2 b-c) \\
& Q_{4}=2 b m /(2 b-c), \text { and } \\
& R=(1-t) /\left(1-\sigma^{*}\right)\left(1-t^{*}\right) .
\end{aligned}
$$


FIGURE 1

NASH EQUILIBRIA FOR $(\eta, F)$ COMBINATIONS

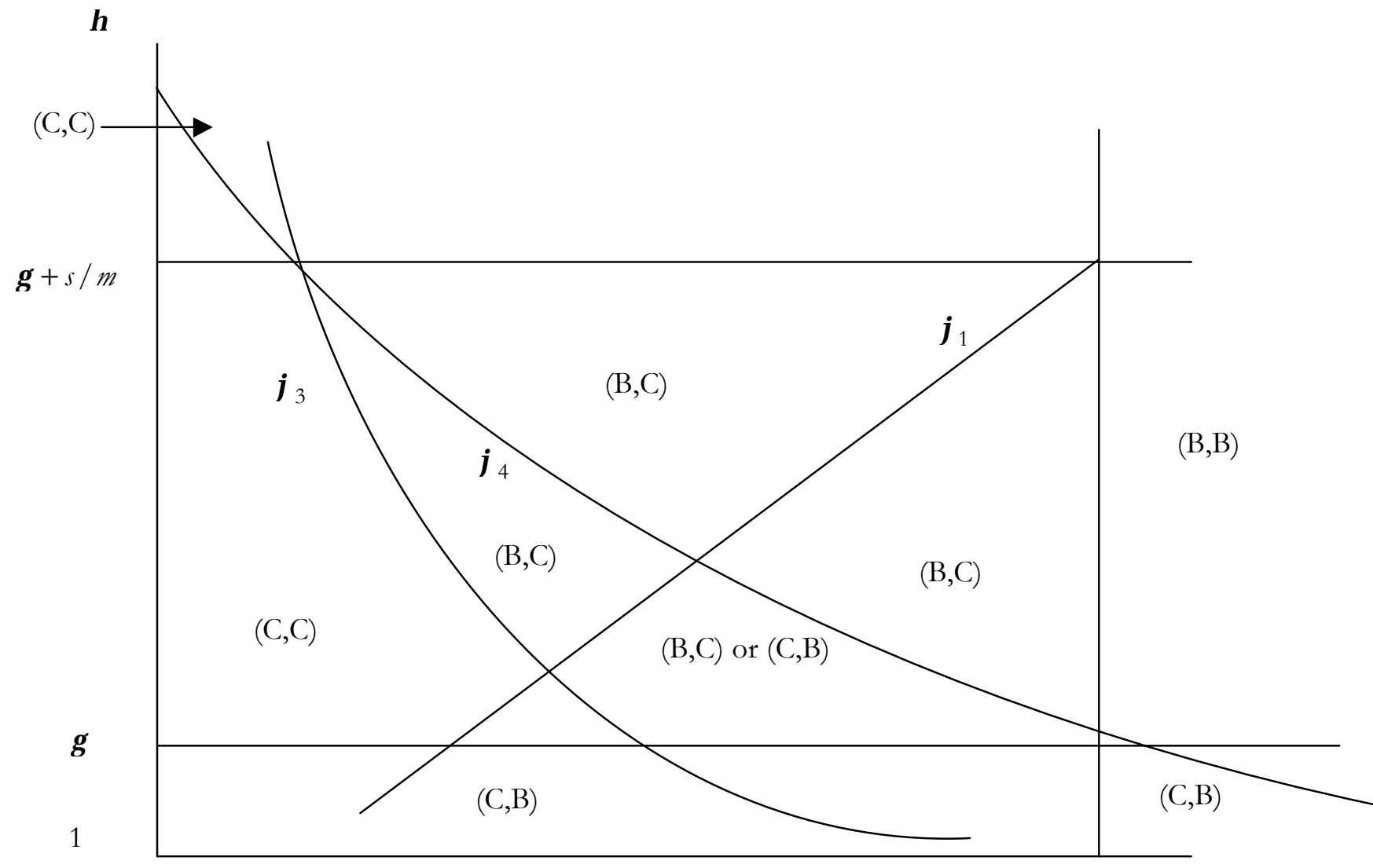

$9 b F / 4$ 
FIGURE 2

NASH EQUILIBRIA FOR $(\eta, F)$ COMBINATIONS WITH FOREIGN TAX

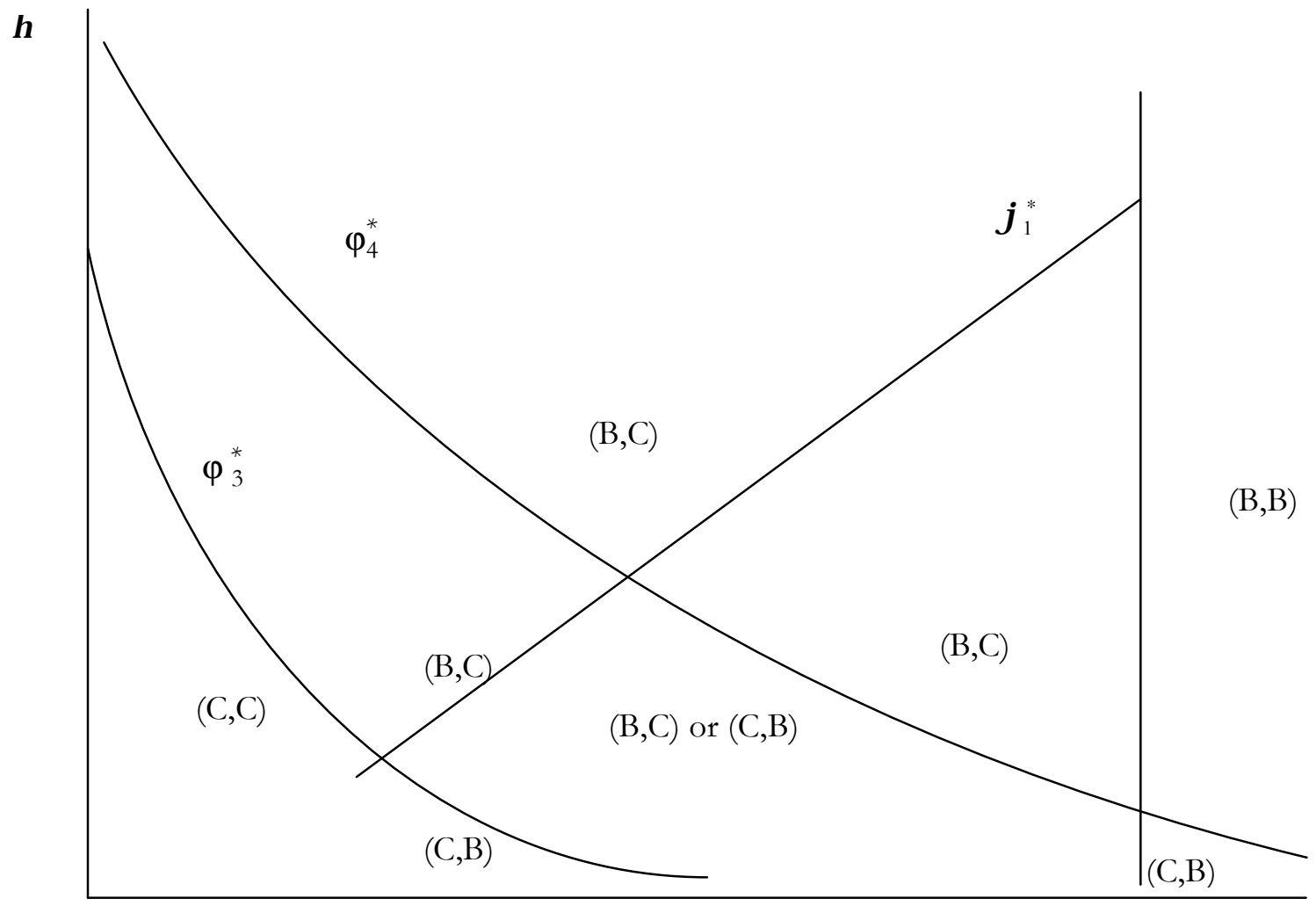

$\varphi_{2}^{*}$ 


\section{FIGURE 3}

Welfare Comparion With No Foreign Taxes: Deferral v. Accrual $\mathrm{a}=3, \mathrm{~b}=1, \mathrm{c}=0.8, \mathrm{~m}=\mathrm{s}=0.5, \mathrm{t}=0.5, \mathrm{~A}=0.4$

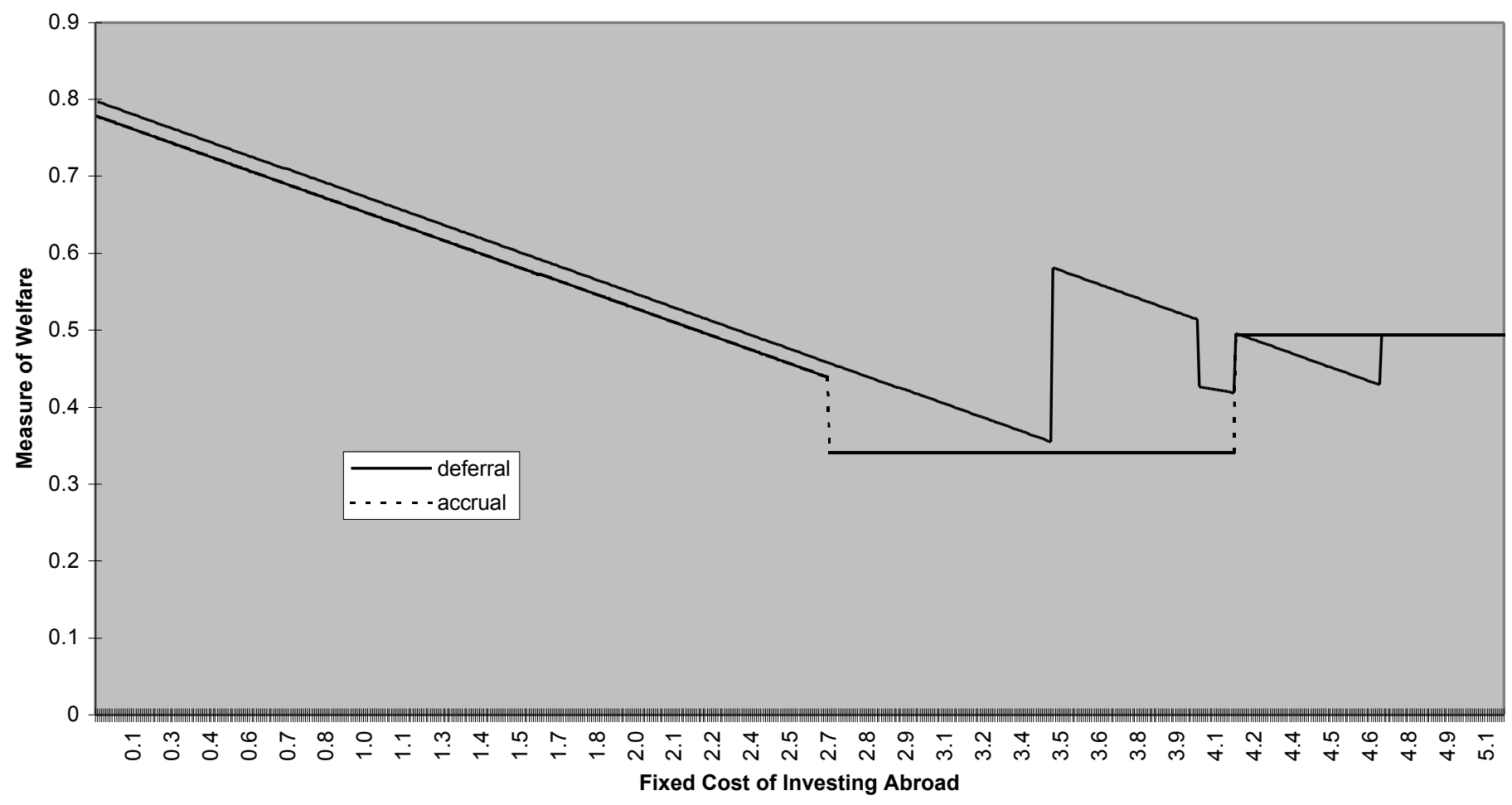


FIGURE 4

Welfare Comparison: Partial Credit With Deferral v. Deduction Without Deferral $\mathrm{a}=3, \mathrm{~b}=1, \mathrm{c}=0.8, \mathrm{~m}=\mathrm{s}=0.5, \mathrm{t}=0.5, \mathrm{~A}=0.4, \mathrm{t}_{\mathrm{f}}=0.2, \mathrm{~A}_{\mathrm{f}}=0.16$

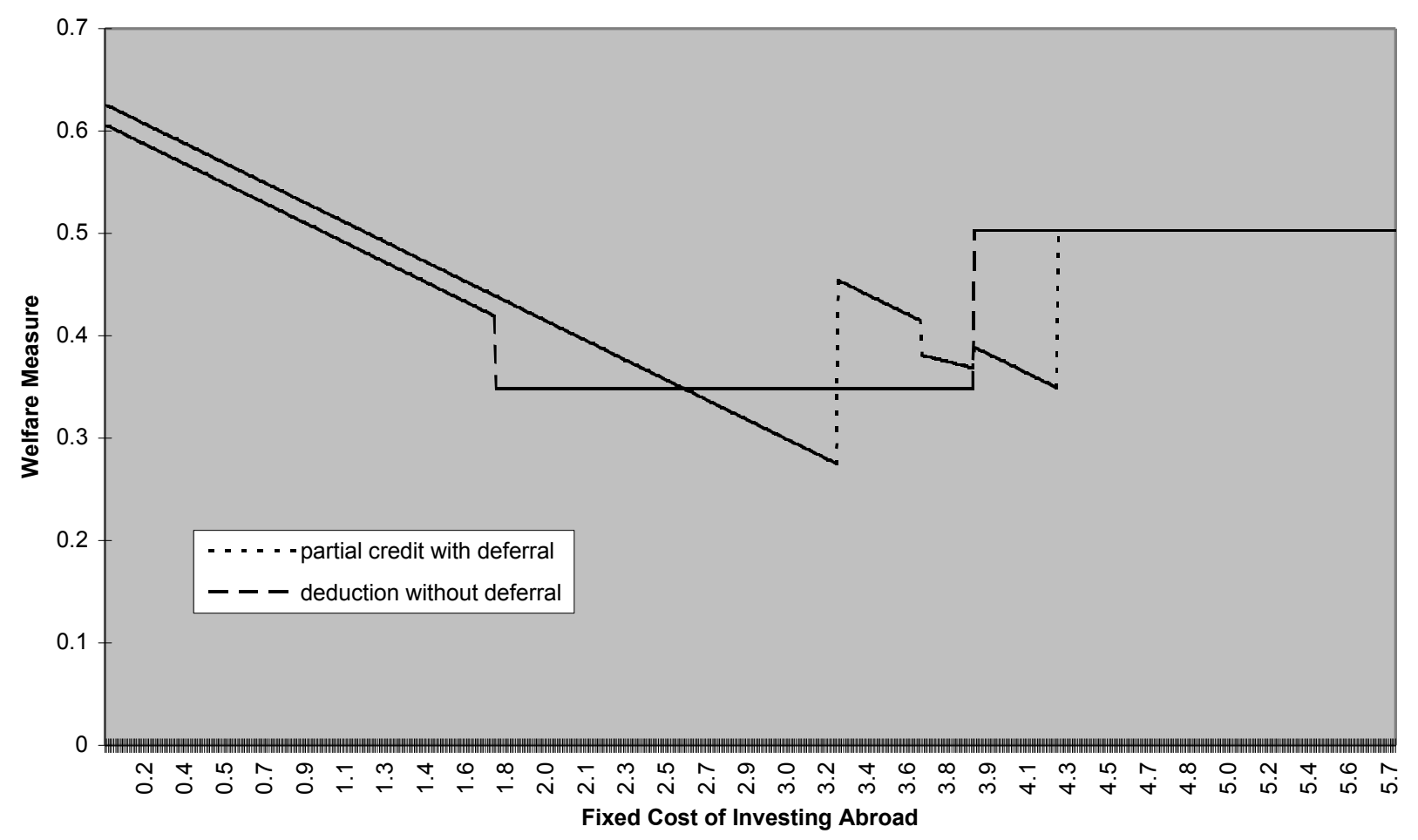




\section{FIGURE 5}

Welfare Comparison With High Foreign Tax:

Partial Credit With Deferral v. Deduction Without Deferral

$\mathrm{a}=3, \mathrm{~b}=1, \mathrm{c}=0.8, \mathrm{~m}=\mathrm{s}=0.5, \mathrm{t}=0.5, \mathrm{~A}=0.4, \mathrm{t}_{\mathrm{a}}=0.6, \mathrm{~A}_{\mathrm{a}}=0.48$

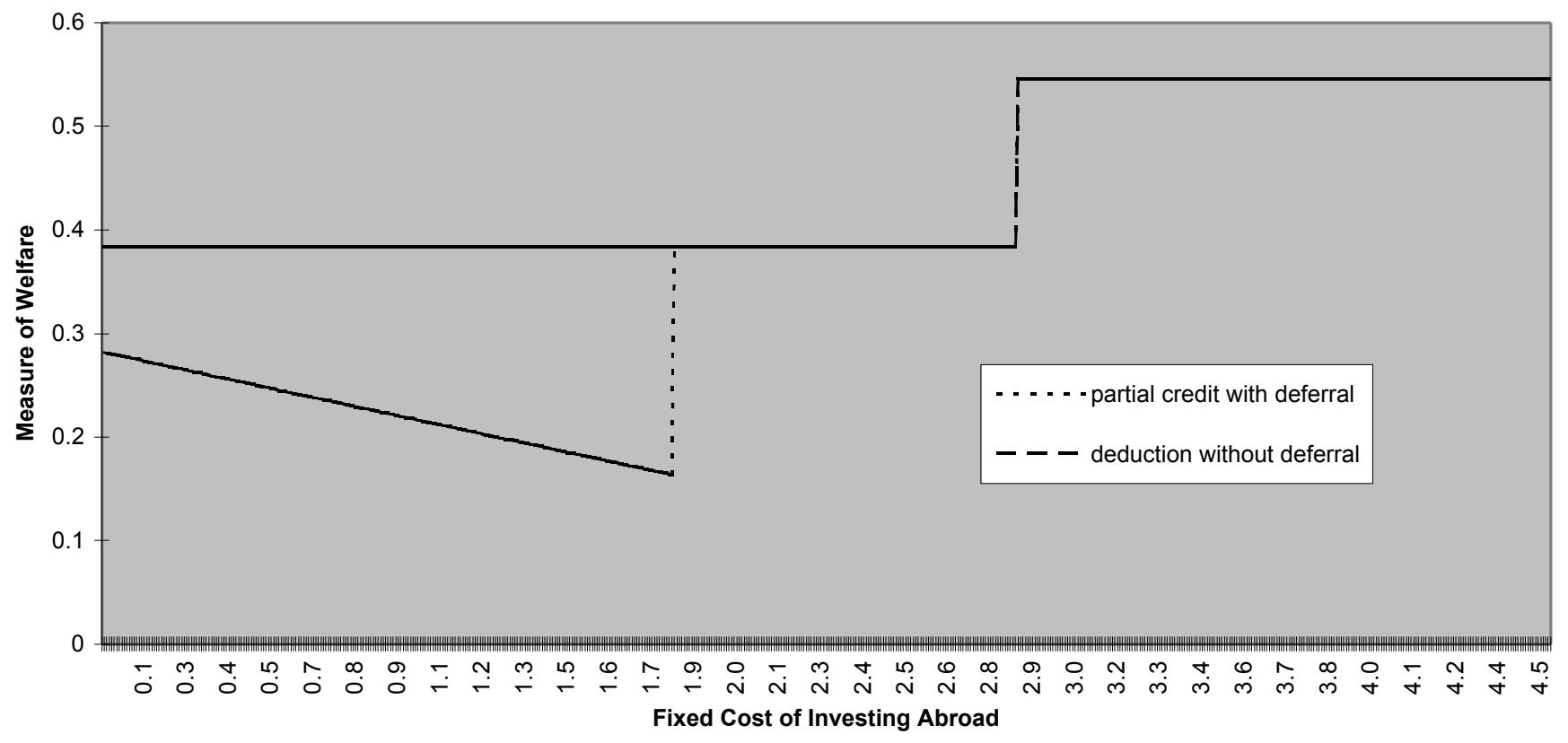

